\title{
Pengaruh Pemberlakuan Rekayasa Lalulintas Terhadap Derajat Kejenuhan Pada Simpang Jalan Pajajaran dan Jalan Pasirkaliki
}

\author{
Risna Rismiana Sari \\ Jurusan Teknik Sipil, Politeknik Negeri Bandung, Bandung 40012 \\ E-mail: risnars@polban.ac.id
}

\begin{abstract}
ABSTRAK
Pesatnya pertumbuhan volume lalulintas di Kota Bandung memiliki berbagai dampak, salah satunya pada simpang bersinyal Jalan Pajajaran-Jalan Pasirkaliki. Tingginya nilai derajat kejenuhan terutama pada saat-saat jam sibuk mengakibatkan antrian yang cukup panjang serta tundaan yang besar. Untuk mengantisipasi hal tersebut, perlu diperhitungkan pemberlakuan rekayasa lalulintas guna meningkatkan pelayanan simpang dengan prasarana simpang yang tersedia. Analisis yang dilakukan mengacu pada Manual Kapasitas Jalan Indonesia (MKJI) 1997. Pemberlakuan rekayasa jalan yang dilaksanakan berhasil menurunkan nilai derajat kejenuhan simpang secara signifikan. Nilai derajat kejenuhan pada kondisi eksisting pada pendekat selatan, utara, dan barat masing-masing adalah 1.59 , 1.97, dan 1.78 mengalami penurunan, yaitu pada pendekat selatan adalah 0.41 , pendekat utara adalah 0.81 dan 0.53, pendekat barat adalah 1.01 dan 0.41. Penurunan nilai derajat kejenuhan akan memberikan kenyamanan kepada pengguna jalan karena waktu tundaan menjadi lebih singkat.
\end{abstract}

Kata kunci:

Simpang, rekayasa lalulintas, derajat kejenuhan, MKJI 1997

\section{PENDAHULUAN}

Pertumbuhan volume lalu lintas jalan khususnya di Kota Bandung terus meningkat akibat dari pertumbuhan dan perkembangan kota serta laju pertumbuhan penduduk. Pertumbuhan volume lalulintas yang tidak diiringi dengan pertambahan pembangunan infrastruktur jalan seringkali mengakibatkan kemacetan. Kemacetan lalulintas merupakan masalah utama di kota besar yang terutama dirasakan pada jam-jam sibuk, baik pagi maupun sore hari [1].

Akibat dari pesatnya pertumbuhan volume lalu lintas di Kota Bandung salah satunya dapat dirasakan pada simpang bersinyal Jalan Pajajaran dan Jalan Pasirkaliki. Padatnya kendaraan terutama pada saat-saat jam sibuk mengakibatkan antrian yang cukup panjang serta tundaan yang besar. Hal ini memberikan cukup perhatian agar permasalahan dapat segera diatasi.

Salah satu penanganan yang telah dilaksanakan di lapangan adalah dengan pemberlakuan rekayasa lalu lintas. Rekayasa lalu lintas adalah suatu penanganan yang berkaitan dengan perencanaan, perancangan geometrik dan operasi lalu lintas jaan raya serta jaringannya, terminal, penggunaan lahan serta keterkaitannya dengan moda transportasi lain.

Rekayasa lalulintas yang dilaksanakan pada simpang ini adalah dengan mematikan sinyal dan mengatur pergerakan kendaraan sehingga tidak terjadi antrian yang panjang pada lengan-lengan simpang. Dengan pemberlakuan rekayasa lalulintas ini diharapkan nilai derajat kejenuhan pada simpang dapat diturunkan sehingga kenyamanan pengguna jalan dapat dipertahankan.

\section{TINJAUAN PUSTAKA}

\subsection{Persimpangan}

Pertemuan atau persimpangan jalan merupakan simpul transportasi yang terbentuk dari beberapa pendekat dimana arus kendaraan dari beberapa pendekat tersebut bertemu dan memencar meninggalkan persimpangan [2]. Simpang dapat didefenisikan sebagai daerah umum dimana dua jalan atau lebih bergabung atau bersimpangan, termasuk jalan dan fasilitas tepi jalan untuk pergerakan lalulintas di dalamnya.

\subsection{Variabel pada Simpang}

Beberapa variabel yang harus diperhatikan pada simpang adalah sebagai berikut:

a. Arus lalu lintas

Arus lalu lintas berinteraksi dengan sistem jaringan transportasi. Jika arus lalu lintas meningkat pada ruas jalan tertentu, waktu tempuh pasti bertambah (karena kecepatan menurun. Arus maksimum yang dapat melewati suatu ruas jalan bisa disebut kapasitas ruas jalan tersebut [3].

b. Karakteristik volume

Volume adalah sebuah peubah (variabel) yang paling penting pada teknik lalu lintas, dan pada dasarnya merupakan proses perhitungan yang 
berhubungan dengan jumlah gerakan per satuan waktu pada lokasi tertentu [2].

Karakteristik volume lalu lintas pada suatu jalan akan bervariasi tergantung pada volume total dua arah, arah lalu lintas, volume harian, bulanan, dan tahunan serta pada komposisi kendaraan [4].

c. Karakteristik kecepatan

Kecepatan adalah laju perjalanan yang biasanya dinyatakan dalam kilometer per jam ( $\mathrm{km} / \mathrm{jam})$ [2]

d. Alat Pemberi Isyarat Lalu Lintas

Prinsip dasar pengendalian persimpangan dengan alat pemberi isyarat lalu lintas harus memenuhi aturan yang disampaikan oleh isyarat lampu tersebut [4]. Keberhasilan dari pengaturan ini dengan Alat Pemberi Isyarat Lalu Lintas (APILL) ditentukan dengan berkurangnya penundaan waktu untuk melalui persimpangan (waktu antri yang minimal) dan berkurangnya angka kecelakaan pada persimpangan yang bersangkutan. Lampu pengatur (isyarat) lalu lintas merupakan alat yang sederhana (manual, mekanis, elektris), alat ini memberi prioritas bergantian dalam suatu periode waktu.

Penggunaan sinyal pada lampu 3 (tiga) warna (hijau, kuning, merah) bertujuan untuk memisahkan lintas dari gerakan- gerakan lalu lintas yang bertentangan dalam dimensi waktu [5]. Hal ini adalah mutlak bagi gerakangerakan lalu lintas yang datang dari jalan saling konflik. Sinyal juga dapat digunakan untuk memisahkan gerakan konflik yaitu gerakan membelok dari lalu lintas lurus, melawan, atau untuk memisahkan gerakan lalu lintas membelok dari pejalan kaki yang menyeberang.

e. Karakteristik Geometrik

Geometrik persimpangan harus dirancang sehingga mengarahkan pergerakan (manuver) lalu lintas ke dalam lintasan yang paling aman dan paling efisien, dan dapat memberikan waktu yang cukup bagi para pengemudi untuk membuat keputusan-keputusan yang diperlukan dalam mengendalikan kendaraannya [4].

Karakteristik geometrik jalan merupakan gambaran suatu simpang dengan informasi mengenai kereb, jalur, lebar bahu dan median [6].

f. Kondisi Lingkungan

Kondisi lingkungan merupakan faktor penting dalam penentuan jenis simpang. Kondisi lingkungan dapat dibedakan berdasarkan parameter pemukiman, komersial, akses terbatas [5].

g. Unsur Kendaraan

Unsur-unsur kendaraan yang dapat mempengaruhi suatu kondisi di persimpangan adalah sebagai berikut [5]:
1) Unsur lalu lintas

Unsur lalu lintas adalah benda atau pejalan kaki sebagai bagian dari lalu lintas,

2) Kendaraan

Kendaraan adalah unsur lalu lintas di atas roda, dibedakan atas kendaraan ringan, kendaraan berat, sepeda motor dan kendaraan tidak bermotor

\subsection{Data Masukan Simpang Bersinyal}

Data masukan untuk simpang bersinyal yang harus sangat diperhatikan adalah sebagai berikut:

a. Kondisi Geometrik dan Lingkungan

Berisi tentang data lebar jalan, lebar bahu jalan, lebar median dan arah lajur untuk setiap lengan simpang. Kondisi lingkungan dapat berupa komersial, pemukiman, dan akses terbatas.

b. Kondisi Arus Lalu Lintas

Jenis kendaraan dibagi dalam beberapa tipe. Untuk menghitung rasio arus kendaraan yang belok kiri $\left(\mathrm{P}_{\mathrm{LT}}\right)$ dan rasio arus kendaraan yang belok kanan $\left(\mathrm{P}_{\mathrm{RT}}\right)$ untuk masing-masing pendekat dihitung dengan persamaan (1 dan 2) sebagai berikut:

$\mathrm{P}_{\mathrm{RT}}=Q_{R T}\left(\right.$ smp/jam) $/ Q_{\text {total }}($ smp/jam) (1)

$\mathrm{P}_{\mathrm{LT}}=Q_{L T}(\mathrm{smp} / \mathrm{jam}) / Q_{\text {total }}(\mathrm{smp} / \mathrm{jam})$

Dimana:

$\mathrm{Q}_{\mathrm{LT}}=$ Arus Belok Kiri Total

$\mathrm{Q}_{\mathrm{RT}}=$ Arus Belok Kanan Total

$\mathrm{Q}_{\text {total }}=$ Arus Total

c. Penentuan Fase Sinyal

Fase adalah suatu rangkaian dari kondisi yang diberlakukan untuk suatu arus atau beberapa arus, yang mendapatkan identifikasi lampu lalu lintas yang sama [7].

d. Arus Jenuh Dasar $\left(\mathrm{S}_{\mathrm{o}}\right)$

Arus jenuh dasar merupakan besarnya keberangkatan antrian di dalam pendekat selama kondisi ideal (smp/jam hijau).

Untuk tipe pendekat $\mathrm{P}$ dapat dihitung dengan persamaan (3) sebagai berikut :

$\mathrm{S}_{\mathrm{o}}=600 \times \mathrm{W}_{\mathrm{e}}$

Dimana:

$\mathrm{S}_{\mathrm{o}} \quad$ : arus jenuh dasar

$\mathrm{W}_{\mathrm{e}} \quad$ : lebar efektif pendekat

Untuk tipe pendekat $\mathrm{O}$

Lajur belok kanan tidak terpisah, jika $\mathrm{Q}_{\mathrm{RT}}>250 \mathrm{smp} / \mathrm{jam}$ :

- $\mathrm{Q}_{\mathrm{RTO}}<250$,

Tentukan $\mathrm{S}_{\text {prov }}$ pada $\mathrm{Q}_{\mathrm{RTO}}=250$ 
Tentukan S sesungguhnya sebagai

$\mathbf{S}=\mathbf{S}_{\text {prov }}-\left[\left(Q_{\text {RTO }}-250\right) \times 8\right] \mathrm{smp} / \mathrm{jam}$

- $\mathrm{Q}_{\mathrm{RTO}}>250$,

Tentukan Sprov pada $\mathrm{Q}_{\mathrm{RT}}, \mathrm{Q}_{\mathrm{RTO}}=250$

Tentukan $\mathrm{S}$ sesungguhnya sebagai

$\mathrm{S}=\mathrm{S}_{\text {prov }}-\left[\left(\mathrm{Q}_{\mathrm{RTO}}+\mathrm{QRT}_{\mathrm{RT}}-500\right) \times 2\right]$

Jika $\mathrm{Q}_{\mathrm{RTO}}<250$ dan $\mathrm{Q}_{\mathrm{RT}}>250 \mathrm{smp} /$ jam, tentukan $\mathrm{S}$ pada $\mathrm{Q}_{\mathrm{RT}}=250 \mathrm{smp} / \mathrm{jam}$.

e. Faktor Penyesuaian

Faktor Koreksi Ukuran Kota $\left(\mathrm{F}_{\mathrm{CS}}\right)$ dapat ditentukan dari Tabel 1.

Tabel 1. Faktor Koreksi Ukuran Kota $\left(F_{C S}\right)$ untuk Simpang.

\begin{tabular}{|c|c|}
\hline $\begin{array}{c}\text { Jumlah Penduduk } \\
\text { (dalam Juta) }\end{array}$ & $\begin{array}{c}\text { Faktor penyesuaian } \\
\text { ukuran kota }\left(\mathbf{F}_{\mathbf{C S}}\right)\end{array}$ \\
\hline$>3,0$ & 1,05 \\
$1,0-3,0$ & 1,00 \\
$0,5-1,0$ & 0,94 \\
$0,1-1,0$ & 0,83 \\
$<0,1$ & 0,82 \\
\hline
\end{tabular}

Sumber: MKJI 1997

Faktor Penyesuaian untuk Kelandaian $\left(\mathrm{F}_{\mathrm{G}}\right)$ dapat ditentukan dari Gambar 1.

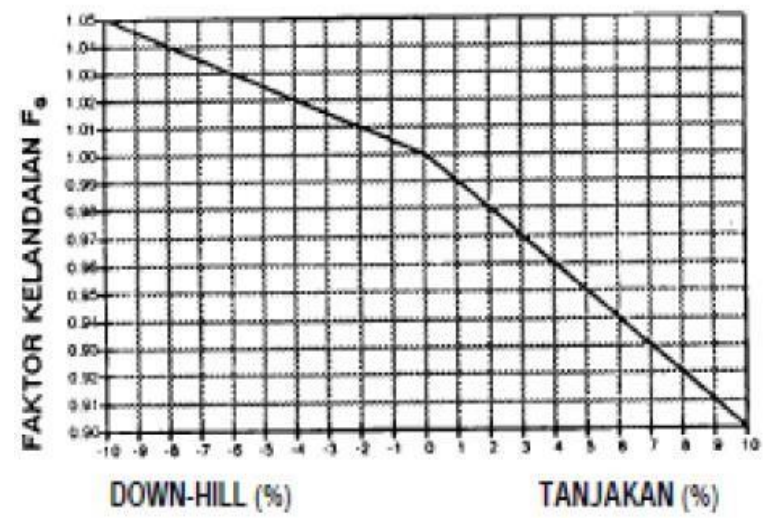

Sumber: MKJI 1997

Gambar 1. Faktor Penyesuaian untuk Kelandaian $\left(\mathrm{F}_{\mathrm{G}}\right)$
Faktor Penyesuaian Hambatan Samping dapat ditentukan dari Tabel 2.

Tabel 2. Faktor Penyesuaian Hambatan Samping

\begin{tabular}{|c|c|c|c|c|c|c|c|c|}
\hline \multirow{2}{*}{$\begin{array}{c}\text { Lingkungan } \\
\text { jalan }\end{array}$} & \multirow{2}{*}{$\begin{array}{l}\text { Hambatan } \\
\text { Samping }\end{array}$} & \multirow{2}{*}{ Tipe Fase } & \multicolumn{6}{|c|}{ Rasio Kendaraan Tak Bermotor } \\
\hline & & & 0,00 & 0,05 & 0,10 & 0,15 & 0,20 & $\geq 0,25$ \\
\hline \multirow{6}{*}{$\begin{array}{c}\text { Komersial } \\
(\mathrm{COM})\end{array}$} & \multirow{2}{*}{ Tinge } & terhwan & 0,93 & 0,88 & 0,84 & 0,79 & 0,74 & 0,70 \\
\hline & & terlindung & 0,93 & 0,91 & 0.88 & 0,87 & 0,85 & 0,81 \\
\hline & \multirow{2}{*}{ Sedang } & terhwan & 0,94 & 0,89 & 0,85 & 0,80 & 0,75 & 0.71 \\
\hline & & terindung & 0,94 & 0,92 & 0,89 & 0.88 & 0,86 & 0,82 \\
\hline & \multirow{2}{*}{ Kecil } & terhwan & 0,95 & 0,90 & 0,86 & 0,81 & 0,76 & 0,72 \\
\hline & & terfindung & 0.95 & 0,93 & 0.90 & 0.89 & 0.87 & 0,83 \\
\hline \multirow{6}{*}{$\begin{array}{l}\text { Pemukiman } \\
\text { (RES) }\end{array}$} & \multirow{2}{*}{ Tinge } & terhwan & 0,96 & 0,91 & 0,86 & 0,81 & 0,78 & 0.72 \\
\hline & & terlindung & 0.96 & 0.94 & 0.92 & 0.99 & 0,86 & 0,84 \\
\hline & \multirow{2}{*}{ Sedang } & terhwan & 0,97 & 0.92 & 0,87 & 0,82 & 0,79 & 0,73 \\
\hline & & terfindung & 0,97 & 0,95 & 0,93 & 0,90 & 0,87 & 0,85 \\
\hline & \multirow{2}{*}{ Kecil } & terhwan & 0,98 & 0,93 & 0,88 & 0,83 & 0,80 & 0,74 \\
\hline & & terlindung & 0,98 & 0,96 & 0,94 & 0,91 & 0,88 & 0,86 \\
\hline \multirow{2}{*}{$\begin{array}{c}\text { Akses Terbatas } \\
\text { (RA) }\end{array}$} & Tingg/Sedang & terhwan & 1,00 & 0,95 & 0,90 & 0,85 & 0,80 & 0,75 \\
\hline & Kecl & terfindung & 1,00 & 0,98 & 0,95 & 0,93 & 0,90 & 0,88 \\
\hline
\end{tabular}

Sumber: MKJI 1997

Faktor Penyesuaian untuk Pengaruh Parkir dan Lajur Belok Kiri yang Pendek $\left(\mathrm{F}_{\mathrm{P}}\right)$ dapat dihitung dengan persamaan (6) sebagai berikut:

$\mathrm{FP}_{\mathrm{P}}=\left[\mathrm{LP} / 3-\left(\mathrm{W}_{\mathrm{A}}-2\right) \mathrm{x}(\mathrm{LP} / 3-\mathrm{g}) / \mathrm{W}_{\mathrm{A}}\right] / \mathrm{g}$

Dimana:

LP = Jarak antara garis henti dan kendaraan yang diparkir pertama (m) (atau panjang dari lajur pendek)

$\mathrm{W}_{\mathrm{A}}=$ Lebar pendekat $(\mathrm{m})$

$\mathrm{G} \quad=$ Waktu hijau pada pendekat (nilai normal 26 detik)

Faktor penyesuaian untuk belok kanan $\left(\mathrm{F}_{\mathrm{RT}}\right)$ dan belok kiri $\left(\mathrm{F}_{\mathrm{LT}}\right)$ \{ hanya berlaku untuk pendekat tipe $\mathrm{P}$, jalan dua arah, lebar efektif ditentukan oleh lebar masuk, tanpa belok kiri langsung (untuk belok kiri)\}, dapat ditentukan dari Gambar 2 dan Gambar 3. 


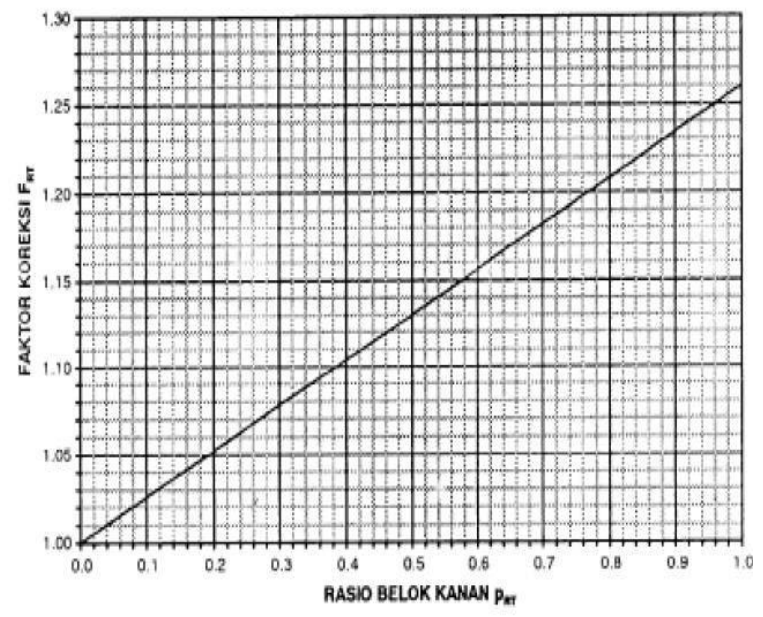

Sumber : MKJI 1997

Gambar 2. Faktor Penyesuaian untuk Belok Kanan ( $\left.F_{R T}\right)$

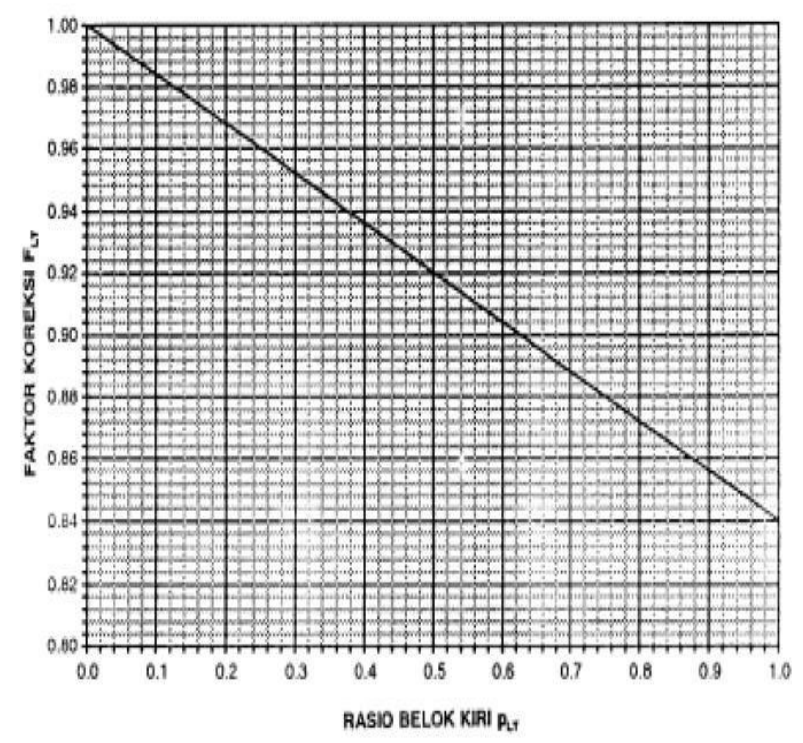

Sumber : MKJI 1997

Gambar 3. Faktor Penyesuaian untuk Belok Kiri $\left(\mathrm{F}_{\mathrm{LT}}\right)$

f. Nilai Arus Jenuh

Nilai arus jenuh dapat dihitung dengan persamaan (7) sebagai berikut:

$S=S_{o} x F_{C S} x \mathrm{~F}_{\mathrm{SF}} x F_{G} x F_{P} x F_{R T} x F_{L T}$

Dimana:

$\mathrm{S}_{\mathrm{o}} \quad$ : arus jenuh dasar

$\mathrm{F}_{\mathrm{CS}}$ : faktor koreksi ukuran kota

$\mathrm{F}_{\mathrm{SF}}$ : faktor koreksi hambatan samping

$\mathrm{F}_{\mathrm{G}}$ : faktor koreksi kelandaian

$\mathrm{F}_{\mathrm{P}}$ : faktor koreksi parkir

$\mathrm{F}_{\mathrm{RT}}$ : faktor koreksi belok kanan

$\mathrm{F}_{\mathrm{LT}}$ : faktor koreksi belok kiri Waktu hijau
Waktu hijau untuk setiap fase dapat dihitung dengan menggunakan persamaan 8 .

$g_{i}=\left(C_{u a}-L T I\right) \times P R_{i}$

Dimana:

$$
\begin{aligned}
g_{i}= & \text { waktu hijau dalam fase }-i \text { (detik) } \\
C_{\text {ua }}= & \text { waktu siklus yang ditentukan } \\
& (\text { detik }) \\
L T I= & \text { total waktu hilang per-siklus } \\
= & \sum(\text { allred }+ \text { amber }) i=\Sigma I G i \\
P R_{i}= & \text { perbandingan fase } \\
& F R_{C R I T} / \Sigma\left(F R_{C R I T}\right) \\
I G i= & \text { Waktu antar hijau pada pendekat } \mathrm{i}
\end{aligned}
$$

Waktu hijau yang lebih pendek dari 10 detik harus dihindarkan. Hal ini mungkin akan menghasilkan terlalu banyak pengemudi yang berlawanan setelah lampu merah dan kesulitan bagi pejalan kaki untuk menyeberang jalan.

Waktu siklus untuk fase dapat dihitung dengan persamaan 9. Waktu siklus hasil perhitungan ini merupakan waktu siklus optimum yang menghasilkan tundaan terkecil.

$$
C_{u a}=\frac{(1.5 \times L T I+5)}{(1-I F R)}
$$

Dimana:

g. Waktu Hijau dan Waktu Siklus

$C_{\text {иа }}=$ waktu siklus sinyal (detik)

LTI = total waktu hilang per-siklus (detik)

$I F R=$ perbandingan arus simpang

$$
\Sigma\left(\mathrm{FR}_{\mathrm{CRIT}}\right)
$$

Fase sinyal yang menghasilkan nilai terendah dari (IFR + LTI / c) adalah yang paling efisien. Waktu siklus yang disarankan oleh MKJI 1997, dapat dilihat pada Tabel 3.

Tabel 3. Waktu Siklus yang Disarankan

\begin{tabular}{|c|c|}
\hline Tipe kontrol & Waktu siklus yang layak (detik) \\
\hline 2 fase & $40-80$ \\
3 fase & $50-100$ \\
4 fase & $80-130$ \\
\hline
\end{tabular}

\section{Sumber: MKJI 1997}

Waktu siklus sangat berpengaruh terhadap kapasitas simpang. Namun harus dipertimbangkan, waktu siklus yang rendah akan mempersulit pejalan kaki untuk menyeberang jalan, sedangkan waktu siklus yang lebih besar dari yang disarankan harus dihindari kecuali untuk kasus yang sangat khusus.

Waktu siklus ini berdasar pada pembulatan waktu hijau yang diperoleh dan waktu hijau hilang (LTI).

$c=\Sigma g+\mathrm{LTI}$ 


\subsection{Kinerja Simpang}

Kualitas dari simpang dapat terlihat dari parameterparameter berikut:

a. Kapasitas

Kapasitas pendekat simpang bersinyal menurut MKJI 1997 dapat dinyatakan dengan rumus 11 berikut:

$$
C=S \times g / c
$$

Dimana:

$C=\operatorname{kapasitas}(\mathrm{smp} / \mathrm{jam})$

$S=$ arus jenuh

$g \quad=$ waktu hijau (det).

$c=$ waktu siklus

b. Derajat Kejenuhan

Jika penentuan waktu sinyal sudah dikerjakan secara benar, derajat kejenuhan akan hampir sama dalam semua pendekat-pendekat kritis. Derajat kejenuhan diperoleh dengan rumus 12 berikut.

$D S=Q / C$

Dimana:

$Q=\operatorname{arus~lalulintas}(\mathrm{smp} / \mathrm{jam})$

$C=$ kapasitas $(\mathrm{smp} / \mathrm{jam})$

\section{METODE PENELITIAN}

Secara keseluruhan, tahapan penelitian yang dilaksanakan dapat dilihat pada bagan alir pada Gambar 4.

Simpang yang diteliti adalah Simpang Jalan Pajajaran dan Jalan Pasirkaliki yang merupakan simpang bersinyal. Data yang dibutuhkan adalah:

a. Kondisi geometrik jalan meliputi: jumlah lajur, lebar lajur, lebar lengan simpang dan lebar LTOR (lajur belok kiri langsung), median dan kelandaian.

b. Data volume kendaraan pada masing-masing lengan.

c. Data fase dan sinyal yang meliputi waktu siklus, waktu hijau aktual, waktu hijau efektif, waktu kuning, dan all red untuk masing-masing lengan.

d. Data jumlah penduduk Kota Bandung.

Alat penelitian yang digunakan adalah formuir survey, hand counter, alat penunjuk waktu, roll meter dan kamera.

Setelah didapatkan data dari hasil survei yang dilakukan di lapangan, kemudian dilakukan hal-hal sebagai berikut:

1. Membuat rekapitulasi dari hasil perhitungan volume kendaraan di lapangan.

2. Melakukan perhitungan nilai volume dan kapasitas berdasarkan teori yang mengacu pada MKJI 1997 pada saat diberlakukan sinyal lalu lintas.
3. Melakukan perhitungan nilai volume dan kapasitas berdasarkan teori yang mengacu pada MKJI 1997 pada saat diberlakukan rekayasa lalu lintas.

4. Membandingkan derajat kejenuhan simpang pada saat diberlakukan sinyal lalulintas dan rekayasa lalulintas.

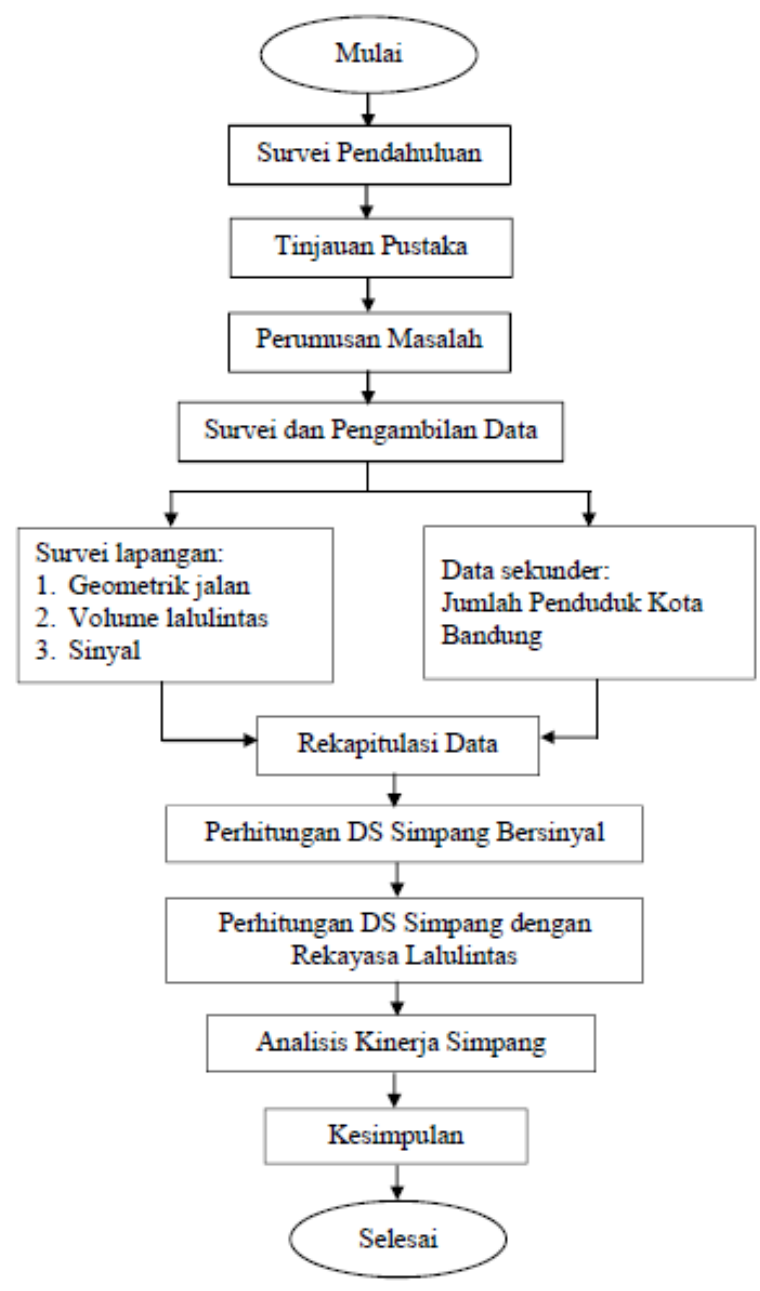

Gambar 4. Bagan alir penelitian

\section{ANALISIS DAN PEMBAHASAN}

\subsection{Geometrik Simpang}

Kondisi geometrik simpang dapat dilihat pada Gambar 5 berikut. 


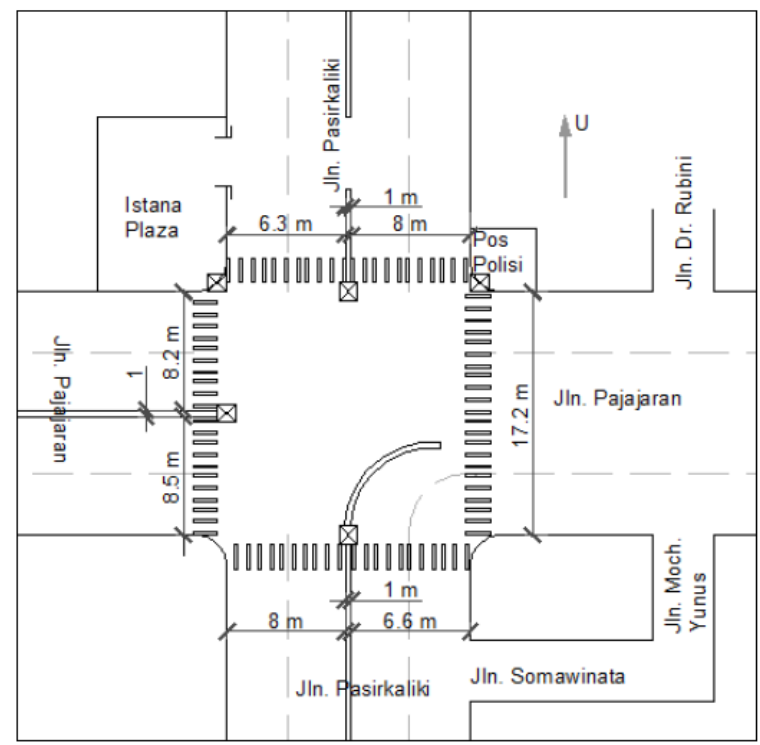

Gambar 5. Geometrik Simpang

Lokasi persimpangan berada pada kawasan komersial dengan jumlah penduduk Kota Bandung pada tahun 2015 adalah 2.394.873 juta jiwa.

\subsection{Volume lalulintas}

Volume lalulintas didapatkan dari hasil survey langsung di lapangan. Data volume lalulintas pada jam puncak untuk masing-masing lengan seperti ditampilkan pada Tabel 4 berikut.

Tabel 4. Data Volume lalu lintas

\begin{tabular}{|c|c|c|c|c|c|c|c|c|c|c|c|c|}
\hline \multirow{3}{*}{ Waktul } & \multicolumn{10}{|c|}{ PENDEKAT SELATAN(kend/15 menit) } \\
\cline { 2 - 15 } & \multicolumn{4}{|c|}{ Lunus } & \multicolumn{3}{|c|}{ Belok Kiri } & \multicolumn{3}{c|}{ Belok Kanan } \\
\cline { 2 - 14 } & LV & HV & MC & UM & LV & HV & MC & UM & LV & HV & MC & UM \\
\hline $13.45-14.00$ & 103 & 5 & 169 & 9 & 74 & - & 117 & 5 & 111 & 5 & 123 & 9 \\
\hline $14.00-14.15$ & 131 & 2 & 243 & 14 & 88 & 3 & 132 & 1 & 157 & 7 & 154 & 13 \\
\hline $14.15-14.30$ & 167 & 1 & 288 & 6 & 86 & 1 & 154 & 7 & 188 & 5 & 189 & 5 \\
\hline $14.30-14.45$ & 185 & 1 & 324 & 17 & 107 & - & 186 & 3 & 203 & 1 & 177 & 7 \\
\hline
\end{tabular}

\begin{tabular}{|c|c|c|c|c|c|c|c|c|c|c|c|c|}
\hline \multirow{3}{*}{ Waktu } & \multicolumn{10}{|c|}{ PENDEKAT UTARA (kend/15 menit) } \\
\cline { 2 - 14 } & \multicolumn{3}{|c|}{ Lurus } & \multicolumn{8}{|c|}{ Belok Kiri } & \multicolumn{3}{c|}{ Belok Kanan } \\
\cline { 2 - 13 } & LV & HV & MC & UM & LV & HV & MC & UM & LV & HV & MC & UM \\
\hline $13.45-14.00$ & & & & & 113 & 1 & 222 & 3 & 242 & 11 & 562 & 4 \\
\hline $14.00-14.15$ & & & & & 125 & 1 & 242 & 1 & 286 & 7 & 595 & 2 \\
\hline $14.15-14.30$ & & & & & 128 & 4 & 255 & 1 & 315 & 5 & 657 & 6 \\
\hline $14.30-14.45$ & & & & & 137 & 2 & 269 & 0 & 343 & 5 & 682 & 1 \\
\hline
\end{tabular}

\begin{tabular}{|c|c|c|c|c|c|c|c|c|c|c|c|c|}
\hline \multirow{3}{*}{ Waktul } & \multicolumn{10}{|c|}{ PENDEKAT BARAT (kend/15 menit) } \\
\cline { 2 - 15 } & \multicolumn{3}{|c|}{ Lurus } & \multicolumn{6}{|c|}{ Belok Kiri } & \multicolumn{3}{c|}{ Belok Kanan } \\
\cline { 2 - 14 } & LV & HV & MC & UM & LV & HV & MC & UM & LV & HV & MC & UM \\
\hline $13.45-14.00$ & 196 & 7 & 291 & 9 & 141 & 4 & 148 & 7 & & & & \\
\hline $14.00-14.15$ & 281 & 11 & 318 & 7 & 159 & 3 & 186 & 6 & & & & \\
\hline $14.15-14.30$ & 318 & 9 & 366 & 5 & 163 & 4 & 191 & 4 & & & & \\
\hline $14.30-14.45$ & 369 & 5 & 397 & 3 & 187 & 1 & 198 & 1 & & & & \\
\hline
\end{tabular}

\subsection{Waktu Siklus}

Pergerakan arus kendaraan pada simpang dibagi kedalam tiga fase. Waktu siklus yang diberlakukan di lapangan adalah 130 detik dengan pembagian sinyal merah, kuning dan hijau dapat dilihat pada Tabel 5 berikut.

Tabel 5. Perbandingan Waktu Sinyal

\begin{tabular}{|c|c|c|c|c|}
\hline Pendekat & Red (det) & Green (det) & Amber (det) & Waktu Siklus (det) \\
\hline Selatan & 97 & 30 & 3 & 130 \\
\hline Utara & 87 & 40 & 3 & 130 \\
\hline Barat & 82 & 45 & 3 & 130 \\
\hline
\end{tabular}

4.4. Derajat Kejenuhan

b. Derajat Kejenuhan Simpang Kondisi Eksisting

Salah satu yang memperlihatkan baik buruknya kinerja simpang adalah derajat kejenuhan. Untuk simpang dengan pemberlakukan sinyal lalulintas, waktu sinyal merupakan salah satu factor yang sangat mempengaruhi kinerja. Nilai Derajat Kejenuhan pada kondisi eksisting yaitu dengan pemberlakuan sinyal lalulintas yang ada saat ini dapat dilihat pada Tabel 6 berikut.

Tabel 6. Derajat Kejenuhan Simpang Kondisi Eksisting

\begin{tabular}{|l|r|r|c|}
\hline \multicolumn{1}{|c|}{ Pendekat } & Q(smpljam) & C (smpljam) & DS \\
\hline Selatan & 802.50 & 503.69 & 1.59 \\
\hline Selatan (belok kanan, lajur terpisah) & 841.35 & $3,207.60$ & 0.26 \\
\hline Utara & $1,721.60$ & 874.63 & 1.97 \\
\hline Barat & $1,480.00$ & 832.46 & 1.78 \\
\hline Timur (satu arah) & $4,230.35$ & $6,415.20$ & 0.66 \\
\hline
\end{tabular}

Pendekat selatan merupakan jalan satu arah dengan pergerakan berbelok kanan langsung dengan lajur terpisah. Pendekat timur merupakan jalan satu arah dengan pergerakan khusus keluar dari simpang.

Dari hasil analisis didapatkan nilai derajat kejenuhan yang sangat tinggi. Hal ini memperlihatkan kondisi lalulintas yang sangat padat bahkan jenuh.

b. Derajat Kejenuhan Simpang dengan Pemberlakuan Rekayasa Lalulintas

Rekayasa lalulintas yang sering diberlakukan pada Simpang Jalan Pajajaran dan Jalan Pariskaliki ini adalah dengan mematikan sinyal lalulintas dan mengatur pergerakan kendaraan. Kondisi simpang dan pergerakan arus dengan pemberlakuan rekayasa lalulintas dapat dilihat pada Gambar 6. 


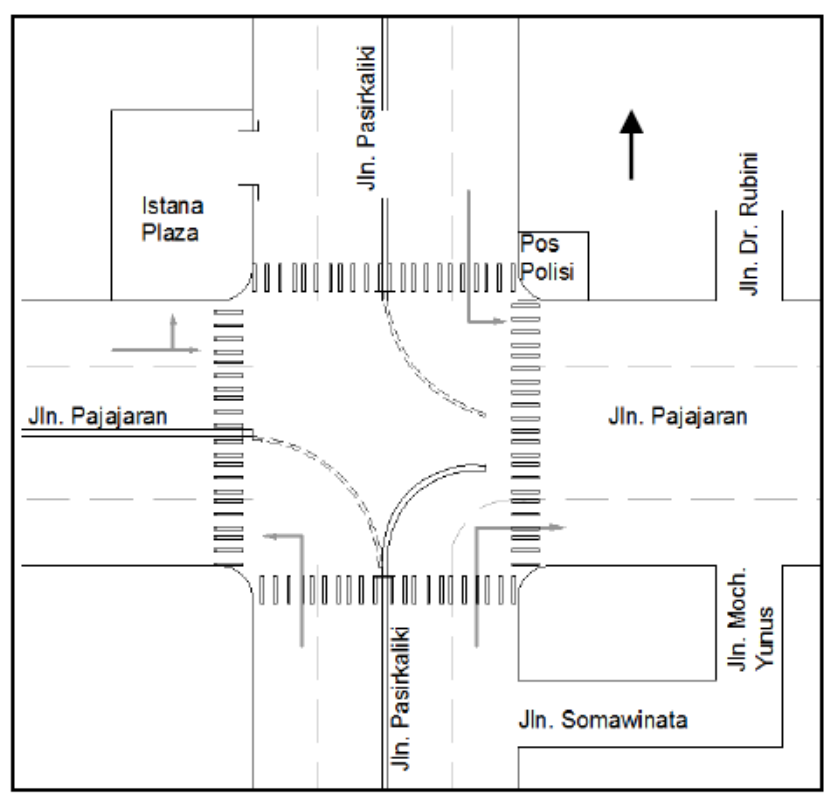

Gambar 6. Pergerakan Arus Dengan Pemberlakuan Rekayasa Lalulintas

Dengan pemberlakuan rekayasa lalulintas ini mengakibatkan perubahan pergerakan kendaraan. Kendaraan yang semula tertahan oleh lampu sinyal lalulintas, dengan pemberlakuan rekayasa lalulintas ini akan berjalan menerus namun dengan pengaturan arah pergerakan.

Nilai Derajat Kejenuhan dengan pemberlakuan rekayasa lalulintas yang ada saat ini dapat dilihat pada Tabel 7 berikut.

Tabel 7. Derajat Kejenuhan Simpang dengan Pemberlakuan Rekayasa lalulintas

\begin{tabular}{|c|c|r|r|c|}
\hline Pendekat & Menuju arah & $Q$ (smp/jam) & $C$ (smp/jam) & DS \\
\hline \multirow{3}{*}{ Selatan } & Utara & $1,329.85$ & $3,207.6$ & 0.41 \\
\cline { 2 - 5 } & Utara (lajur terpisah) & 841.35 & $3,207.6$ & 0.26 \\
\hline \multirow{2}{*}{ Utara } & Selatan & $2,603.20$ & $3,207.6$ & 0.81 \\
\cline { 2 - 5 } & Utara & $1,697.95$ & $3,207.6$ & 0.53 \\
\hline \multirow{2}{*}{ Barat } & Timur & $3,243.35$ & $3,207.6$ & 1.01 \\
\cline { 2 - 5 } & Barat & $1,329.85$ & $3,207.6$ & 0.41 \\
\hline Timur & Timur(satu arah) & $4,230.35$ & $6,415.2$ & 0.66 \\
\hline
\end{tabular}

Dari hasil analisis pada Tabel 7 dapat dilihat bahwa nilai derajat kejenuhan rata-rata pada setiap pendekat $\leq 0.75$. Derajat kejenuhan sedikit tinggi berada pada pendekat utara menuju selatan dengan nilai 0.81 dan pada pendekat barat menuju timur dengan nilai 1.01. Nilai pada pendekat barat menuju timur ini lebih tinggi dibandingkan dengan pendekat yang lain dikarenakan adanya pergerakan dari selatan menuju utara yang akhirnya harus memasuki pendekat barat terlebih dahulu sebelum berbelok kearah utara.

\subsection{Analisis Kinerja Simpang}

Berdasarkan hasil perhitungan derajat kejenuhan simpang dengan kondisi eksisting yaitu dengan pemberlakuan sinyal dan dengan pemberlakuan rekayasa lalulintas, maka dapat dapat diketahui bahwa nilai derajat kejenuhan dengan pemberlakuan rekayasa lalulintas menurun cukup signifikan seperti ditampilkan pada Tabel 8 berikut.

Tabel 8. Perbandingan Nilai Derajat Kejenuhan Simpang

\begin{tabular}{|l|c|c|l|}
\hline \multirow{2}{*}{ Pendekat } & \multicolumn{3}{|c|}{ Derajat Kejenuhan } \\
\cline { 2 - 4 } & Eksisting & \multicolumn{2}{|c|}{ Rekayasa Lalulintas } \\
\hline Selatan & 1.59 & 0.41 & \\
\hline $\begin{array}{l}\text { Selatan (belok kanan } \\
\text { lajur terpisah) }\end{array}$ & 0.26 & 0.26 & \\
\hline Utara & 1.97 & 0.82 & Jalur 1 (arah ke selatan) \\
\cline { 3 - 4 } & 1.78 & 0.53 & Jalur 2 (arah ke utara) \\
\cline { 3 - 4 } Barat & 0.41 & Jalur 2 (arah ke barat) \\
\hline Timur (satu arah) & 0.66 & 0.66 & \\
\hline
\end{tabular}

Nilai derajat kejenuhan pada kondisi eksisting pada pendekat selatan, utara, dan barat masing-masing adalah 1.59, 1.97, dan 1.78. Hal ini memperlihatkan kondisi simpang sangat jenuh. Nilai derajat kejenuhan dengan diberlakukannya rekayasa lalulintas mengalami penurunan, yaitu pada pendekat selatan adalah 0.41 , pendekat utara adalah 0.81 dan 0.53 , pendekat barat adalah 1.01 dan 0.41 .

Nilai derajat kejenuhan pada pendekat selatan pergerakan khusus berbelok kanan dan pada pendekat timur tidak ada perbedaan dikarenakan tidak terpengaruh oleh sinyal laulintas yaitu 0.26 dan 0.66 .

Dengan penurunan nilai derajat kejenuhan ini artinya kepadatan pada simpang dapat direduksi cukup baik. Penurunan derajat kejenuhan pada simpang dapat pula menurunkan nilai tundaan kendaraan, sehingga kenyamanan berkendara dapat ditingkatkan.

\section{KESIMPULAN}

Berdasarkan hasil pembahasan dan analisis pada bab sebelumnya, maka dapat ditarik beberapa kesimpulan sebagai berikut.

\section{Karakteristik Simpang Jalan Pajajaran dan Jalan Pasirkaliki}

Daerah Simpang Jalan Pajajaran-Jalan Pasirkaliki merupakan simpang bersinyal yang berada pada lingkungan komersil. Simpang ini memberlakukan pergerakan berbelok kiri langsung (LTOR) pada setiap lengannya, dan lajur khusus berbelok kanan pada lengan selatan. 
Sinyal yang digunakan adalah sinyal tiga warna dengan urutan merah-hijau kuning. Waktu siklus berdasarkan hasil observasi adalah 130 detik dengan pemberlakuan tiga fase pergerakan.

\section{Kinerja Simpang}

Perberlakuan rekayasa lalulintas pada Simpang Jalan Pajajaran dan Jalan Pasirkaliki memberikan pengaruh yang cukup baik untuk menurunkan nilai derajat kejenuhan. Nilai derajat kejenuhan turun cukup signifikan, sehingga dapat memberikan kenyamanan kepada pengguna jalan dengan tundaan yang lebih singkat dibandingkan dengan kondisi sebelumnya.

Pemberlakuan rekayasa lalulintas merupakan salah satu solusi manajemen lalulintas untuk meningkatkan kapasitas jalan dengan tanpa membutuhkan biaya yang besar untuk pembangunan infrastruktur baru

\section{Daftar Pustaka}

[1] Adisatria, Wiwit. Djakfar, Ludfi. Wicaksono, Achmad. 2015. Manajemen Lalulintas pada Kawasan Tanjung Kabupaten Jember. Jurnal Rekayasa Sipil/Volume 9, N0.1. ISSN 1978-5658.

[2] Hobbs, F. D., 1995. Perencanaan dan Teknik Lalulintas, Edisi Kedua. Penerbit Universitas Gadjah Mada, Yogyakarta.

[3] Tamin, O. Z., 1997. Perencanaan dan Permodelan Transportasi. Penerbit: ITB Press. Bandung.

[4] Abubakar, Iskandar. 1998. Sistem Transportasi Kota. Direktorat Jenderal Perhubungan Darat. Jakarta.

[5] Direktorat Jenderal Bina Marga, Departemen Pekerjaan Umum RI, 1997. Manual Kapasitas Jalan Indonesia. Jakarta.

[6] Sukirman, 1999. Dasar-dasar Perencanaan Geometrik Jalan. Penerbit: Nova. Bandung.

[7] Munawar A., 2004. Manajemen Lalulintas Perkotaan, Edisi Pertama. Penerbit: Beta Offset. Yogyakarta.

[8] Menteri Perhubungan RI, 2006. Peraturan Menteri Perhubungan Nomor KM 14 Tahun 2006 tentang Manajemen dan Rekayasa Lalulintas Di Jalan. 